\title{
Late-Onset Growing Pains
}

\author{
Kenneth J. Zucker
}

Published online: 8 February 2012

(c) Springer Science+Business Media, LLC 2012

As the Archives inches into its fifth decade, it is experiencing some late-onset growing pains. Since I became Editor in 2002, the number of new submissions has risen dramatically (Fig. 1). It began to dawn on me that it was becoming increasingly difficult to keep up with the flow. As I noted last year (Zucker, 2011), I was delighted to appoint five Associate Editors (Lori A. Brotto, Michael P. Carey, Shari L. Dworkin, Marta Meana, and Jeffrey T. Parsons) to assist in the reviewing process. Subsequently, we have added three scholars to the Editorial Board and 25 scholars as Consulting Editors to help us in providing quality peer review: Lisa M. DeBruine, Benedict C. Jones, Carol Lynn Martin, Drew H. Bailey, Andrea Bradford, Carol S. Camlin, Megan S. Dunbar, Rutger C. M. E. Engels, Robyn L. Fielder, Maryanne L. Fisher, Sabina Hirshfield, Roland Imhoff, Kari Lerum, Matthew J. Mimiaga, Angulique Y. Outlaw, Jesse J. Owen, Thomas L. Patterson, Martin Plöderl, Elke D. Reissing, Gerulf Rieger, Stephen T. Russell, Eric W. Schrimshaw, Lori J. Scott-Sheldon, Brooke N. Seal, Theresa E. Senn, Kelly B. Smith, Ana Ventuneac, and Patrick A. Wilson. We now have two father-son pairs on the Board (Bailey and Bailey and Dixson and Dixson): it is unclear if the transmission is genetic or psychosocial. With more submissions, that means that more articles make their way into print. To avoid overweight issues, in

\section{K. J. Zucker ( $\square)$}

Gender Identity Service, Child, Youth, and Family Program,

Centre for Addiction and Mental Health, 250 College St.,

Toronto, ON M5T 1R8, Canada

e-mail: Ken_Zucker@camh.net

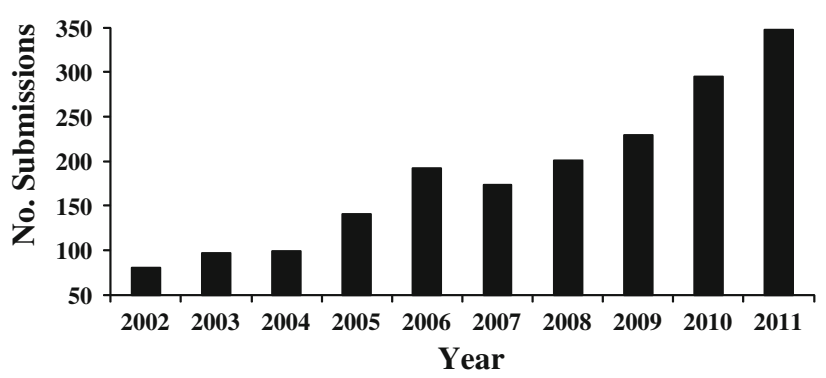

Fig. 1 Number of submissions (2002-2011)

2013 the Journal will publish eight times/year instead of six (C. Bischoff, personal communication, August 24, 2011).

\section{The Impact Factor (IF)}

Calculated each year by the Web of Science ${ }^{\circledR}$ (Thomson Reuters), a journal's IF for a given year is a measure of the frequency with which its recent articles are cited on average during that year. "Recent" refers to the two prior calendar years. Thus, Archives' 2010 IF is the number of times that its 2008 and 2009 articles were cited in 2010, divided by the number of articles the Archives published in 2008 and 2009. Although the IF is the best known metric for citation analysis, there are other measures, including the immediacy index (II) and the cited half-life (CHL). The II is a measure of how frequently the journal's "average article" is cited the same year in which it is published. Thus, the II for a year is calculated as the number of times articles from that journal are cited during that year, divided by the number of articles that journal published that year. The CHL is a measure of the longevity of the frequency of citations to articles in the journal, that is, for how long the average article maintains its currency. The $\mathrm{CHL}$ 
Table 1 Impact factor for the year 2010: Sex- and gender-related journals $(N=67)$

\begin{tabular}{|c|c|c|c|c|c|}
\hline Journal & $\begin{array}{l}\text { Impact } \\
\text { factor }\end{array}$ & $\begin{array}{l}2010 \text { total } \\
\text { cites }\end{array}$ & $\begin{array}{l}2010 \\
\text { articles }\end{array}$ & $\begin{array}{l}\text { Immediacy } \\
\text { index }\end{array}$ & $\begin{array}{l}\text { Cited } \\
\text { half- } \\
\text { life }\end{array}$ \\
\hline Archives of Sexual Behavior & 3.660 & 3,126 & 114 & 1.044 & 7.0 \\
\hline AIDS & 6.348 & 21,706 & 395 & 1.327 & 6.0 \\
\hline Psychoneuroendocrinology & 5.168 & 7,612 & 171 & 0.947 & 5.8 \\
\hline AIDS Reviews & 4.786 & 661 & 20 & 0.200 & 4.2 \\
\hline Human Reproduction & 4.357 & 25,468 & 368 & 0.804 & 7.7 \\
\hline Journal of Acquired Immune Deficiency Syndromes & 4.262 & 11,857 & 305 & 1.046 & 5.4 \\
\hline Hormones and Behavior & 3.991 & 6,833 & 170 & 0.706 & 6.2 \\
\hline Journal of Sexual Medicine & 3.957 & 4,843 & 382 & 0.772 & 2.5 \\
\hline Evolution and Human Behavior & 3.646 & 1,997 & 50 & 0.600 & 6.1 \\
\hline International Journal of Andrology & 3.601 & 2,488 & 93 & 0.699 & 5.5 \\
\hline Menopause & 3.318 & 3,161 & 138 & 1.043 & 3.9 \\
\hline Sexually Transmitted Diseases & 3.268 & 5,308 & 133 & 0.594 & 5.9 \\
\hline AIDS and Behavior & 3.195 & 2,392 & 170 & 0.729 & 3.7 \\
\hline Fertility and Sterility & 3.122 & 25,664 & 844 & 0.716 & 6.9 \\
\hline Sexual Development & 3.052 & 319 & 43 & 0.581 & 2.6 \\
\hline Sexually Transmitted Infections & 3.029 & 3,928 & 165 & 1.327 & 5.0 \\
\hline International Journal of Impotence Research & 2.415 & 2,269 & 50 & 0.360 & 6.7 \\
\hline Journal of Sex and Marital Therapy & 2.364 & 1,500 & 27 & 0.333 & 9.1 \\
\hline AIDS Patient Care and STDs & 2.333 & 1,782 & 89 & 0.326 & 4.2 \\
\hline Psychology of Men and Masculinity & 2.208 & 580 & 25 & 0.28 & 5.5 \\
\hline Body Image & 2.109 & 841 & 57 & 0.298 & 4.5 \\
\hline Politics and Gender & 2.107 & 242 & 19 & 0.158 & 4.1 \\
\hline Gender and Society & 2.088 & 1,749 & 30 & 0.300 & 10.0 \\
\hline Perspectives on Sexual and Reproductive Health & 2.075 & 913 & 38 & 0.289 & 5.8 \\
\hline Hormone Research $^{\mathrm{a}}$ & 2.044 & 3,399 & & & 7.4 \\
\hline AIDS Care & 1.593 & 3,223 & 211 & 0.166 & 5.5 \\
\hline Asian Journal of Andrology & 1.549 & 1,194 & 98 & 0.765 & 4.0 \\
\hline Sexual Abuse: A Journal of Research and Treatment & 1.500 & 757 & 25 & 0.280 & 6.7 \\
\hline Journal of Sex Research & 1.488 & 1,927 & 47 & 0.298 & $>10.0$ \\
\hline Journal of Women's Health & 1.454 & 1,968 & 247 & 0.211 & 4.1 \\
\hline Psychology of Women Quarterly & 1.420 & 1,912 & 44 & 0.795 & $>10.0$ \\
\hline AIDS Education and Prevention & 1.361 & 1,347 & 42 & 0.167 & 7.4 \\
\hline Sexual Health & 1.361 & 435 & 70 & 0.829 & 3.1 \\
\hline Women's Health Issues & 1.287 & 786 & 55 & 0.327 & 5.2 \\
\hline Evolutionary Psychology & 1.278 & 218 & 43 & 0.140 & 3.2 \\
\hline Journal of Psychosomatic Obstetrics and Gynecology & 1.221 & 811 & 32 & 0.156 & 7.9 \\
\hline Sex Roles & 1.213 & 4,075 & 137 & 0.146 & 9.5 \\
\hline Culture, Health, and Sexuality & 1.195 & 582 & 72 & 0.153 & 5.2 \\
\hline International Journal of STD and AIDS & 1.082 & 2,462 & 191 & 0.236 & 6.1 \\
\hline Body and Society & 1.082 & 469 & 25 & 0.360 & 7.1 \\
\hline Gender, Place, and Culture & 1.030 & 499 & 41 & 0.024 & 7.0 \\
\hline Feminism and Psychology & 0.922 & 440 & 35 & 0.229 & 6.8 \\
\hline Women and Health & 0.895 & 1,051 & 47 & 0.106 & 8.7 \\
\hline Feminist Theory & 0.857 & 192 & 19 & 0.000 & 6.0 \\
\hline
\end{tabular}


Table 1 continued

\begin{tabular}{|c|c|c|c|c|c|}
\hline Journal & $\begin{array}{l}\text { Impact } \\
\text { factor }\end{array}$ & $\begin{array}{l}2010 \text { total } \\
\text { cites }\end{array}$ & $\begin{array}{l}2010 \\
\text { articles }\end{array}$ & $\begin{array}{l}\text { Immediacy } \\
\text { index }\end{array}$ & $\begin{array}{l}\text { Cited } \\
\text { half- } \\
\text { life }\end{array}$ \\
\hline Men and Masculinities & 0.814 & 340 & 26 & 0.423 & 5.8 \\
\hline International Perspectives on Sexual and Reproductive Health & 0.806 & 27 & 36 & 0.056 & \\
\hline Australian Feminist Studies & 0.710 & 153 & 37 & 0.027 & 5.8 \\
\hline Sexuality and Disability & 0.674 & 281 & 24 & 0.083 & 9.8 \\
\hline Feminist Review & 0.617 & 336 & 20 & 0.300 & $>10.0$ \\
\hline International Journal of Sexual Health & 0.610 & 39 & 24 & 0.125 & \\
\hline GLQ: A Journal of Gay and Lesbian Studies & 0.588 & 222 & 24 & 0.000 & 7.2 \\
\hline Gender and Education & 0.583 & 512 & 41 & 0.024 & 7.0 \\
\hline European Journal of Women's Studies & 0.579 & 291 & 19 & 0.158 & 4.6 \\
\hline Signs & 0.554 & 1,155 & 43 & 0.070 & $>10.0$ \\
\hline Journal of Gender Studies & 0.551 & 151 & 24 & 0.125 & 6.8 \\
\hline differences: A Journal of Feminist Cultural Studies & 0.548 & 168 & 27 & 0.000 & 8.2 \\
\hline Journal of Homosexuality & 0.436 & 964 & 65 & 0.092 & $>10.0$ \\
\hline Journal of Child Sexual Abuse & 0.359 & 301 & 5 & 2.000 & 7.6 \\
\hline Women's Studies International Forum & 0.333 & 611 & 59 & 0.085 & 9.5 \\
\hline Journal of the History of Sexuality & 0.324 & 144 & 20 & 0.000 & 9.0 \\
\hline Indian Journal of Gender Studies & 0.263 & 37 & 17 & 0.059 & \\
\hline Asian Journal of Women's Studies & 0.206 & 50 & 16 & 0.062 & \\
\hline Zeitschrift für Sexual Forschung & 0.152 & 36 & 17 & 0.000 & \\
\hline Women and Therapy & 0.146 & 182 & 36 & 0.028 & 9.7 \\
\hline Frontiers: Journal of Women's Studies & 0.119 & 80 & 24 & 0.000 & \\
\hline Feministische Studien & 0.074 & 20 & 13 & 0.000 & \\
\hline Feminist Studies & 0.071 & 393 & 28 & 0.000 & $>10.0$ \\
\hline
\end{tabular}

Total cites indicates the total number of times that each journal has been cited by all journals included in the ISI database in 2010. Immediacy index means cites in 2010 to articles published in 2010/number of articles published in 2010. Cited half-life is the median age of its articles cited in the current year. Half of the citations to the journal are to articles published within the cited half-life

${ }^{a}$ Renamed Hormone Research in Paediatrics in 2010; hence, some of the metrics in the table are not available

for a year is determined by the time required to account for a cumulative total of $50 \%$ of that year's citations to the journal.

Table 1 shows the IF of the sex and gender periodicals, broadly defined, for the year 2010. The IF of Archives had a nice jump from 3.23 in 2009 to 3.66 in 2010 . The meaning of the IF can be crudely gauged in comparative perspective: for 2010, of 2,678 Social Science journals, Archives was ranked 93rd (96th percentile). Of 102 journals classified as Psychology (Clinical), Archives was ranked 9th (91st percentile). Of 83 journals classified as Social Science, Interdisciplinary, Archives was ranked 1st. For the first time, Archives surpassed Evolution and Human Behavior by a staggering .014 points (3.660 vs. 3.646). We also closed the gap to .33 to Hormones and Behavior and to .29 to Journal of Sexual Medicine. Perhaps 2011 will bring another great leap forward. ${ }^{1}$

\footnotetext{
1 There are, of course, other kinds of impact factors. As reported in the January/February 2012 issue of SPIN, the post-modern world's premiere music magazine, the album David Comes to Life by my son's band, Fucked
}

There is certainly evidence that articles in this journal are being read (or at least being printed out). Over the past 5 years, the number of articles downloaded were: 93,307 (2007), 141,063 (2008), 194,212 (2009), 321,801 (2010), and, for the first 11 months of 2011, 248,144. A lot of people have time on their hands.

In previous Editorials, I have observed that there are many sex and gender journals that are not given an IF by the Web of Science $^{\circledR}$. I am pleased to note in Table 1 that International Journal of Sexual Health (formerly Journal of Psychology and Human Sexuality) and the Psychology of Men and Masculinity have now joined the numbers game. I would still like to see some other periodicals, such as International Journal of Transgenderism, Journal of Gay and Lesbian Mental Health, Nordic Journal of Feminist and Gender Research, Psychology and Sexuality,

Footnote 1 continued

Up, was ranked as the top album of the year (http://www.spin.com/) (Marchese, 2012). 


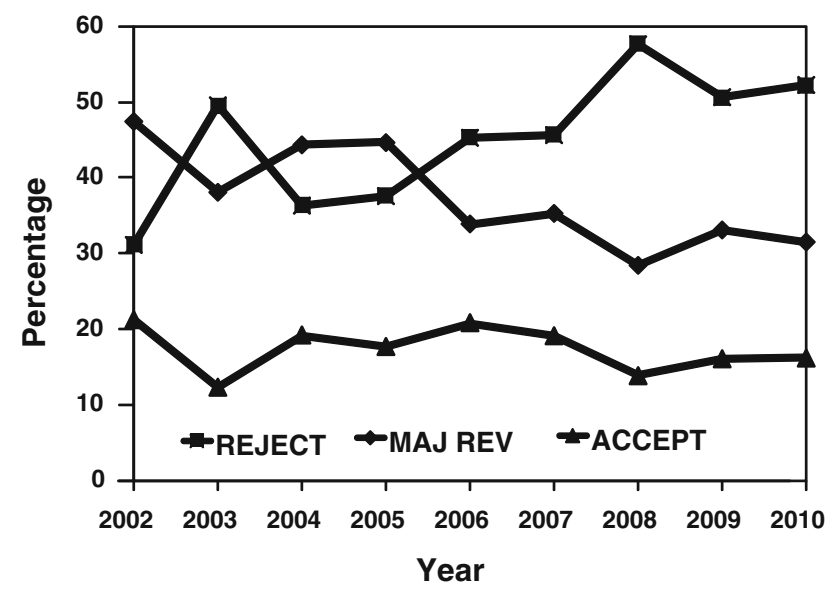

Fig. 2 Manuscript disposition after initial submission (2002-2010)

Sexologies, Sexualities, Sexuality and Culture, and Sexuality Research and Social Policy, enter the fray. In 2012, there will also be at least one new sex and gender periodical: Journal of Language and Sexuality (John Benjamins Publishing Company).

\section{Submissions and Disposition}

Figure 2 shows the Editorial decision data for the original submissions as a function of year (2002-2010). The percentage of manuscripts that were accepted or provisionally accepted ranged from 12.4 to $21.2 \%$; the percentage of manuscripts that were subject to major revision ranged from 28.4 to $47.5 \%$; and the percentage of manuscripts that were rejected ranged from 31.2 to $57.7 \%$. As I noted in last year's Editorial (Zucker, 2011), around $75 \%$ of manuscripts subject to major revision wind up being published in the Journal. The vast majority of the remainder are not resubmitted by the authors.

\section{Transitions}

After serving on the Board for 10 years, Ine Vanwesenbeeck has stepped down. It will be difficult to replace this premier scholar of sex work research. I am delighted to note that Editorial Board member Richard C. Friedman has been appointed Editor of Psychodynamic Psychiatry (formerly the Journal of the American Academy of Psychoanalysis and Dynamic Psychiatry), Editorial Board member Kim Wallen has been appointed Editor of Hormones and Behavior, and Associate Editor Jeffrey T. Parsons has been appointed Editor of Sexuality Research and Social Policy. With the support of the Officers of the International Academy of Sex Research (Cynthia Graham, Erick Janssen, Ellen Laan, and David Moskowitz), I will begin my third 5-year term as Editor in 2012. Lastly, as 2011 came to a close, I began my first term as a grandfather, with the little one born on 28 December (birthweight, $3,090 \mathrm{~g}$ ). Not bad for the final new submission of the year. If I can hold on, she can take over as Editor one day.

\section{References}

Marchese, D. (2012). Fucked up: David comes to life. Album of the Year (pp. 66-69). New York: SPIN.

Zucker, K. J. (2011). The Archives of Sexual Behavior: 40 years on [Editorial]. Archives of Sexual Behavior, 40, 1-4. 